\title{
Drill Method Based on PAIKEM to Improve Children's Speed-Reading Skill
}

\author{
Utami Dewi Pramesti \\ The Study Program of Indonesian Language and Literature \\ Teaching \\ Universitas Negeri Padang \\ Padang, Indonesia \\ dpramesti0405@gmail.com
}

\author{
Malta Nelisa \\ The Study Program of Information, Library, and Archive \\ Universitas Negeri Padang \\ Padang, Indonesia \\ malta@fbs.unp.ac.id
}

\begin{abstract}
This article described the implementation of drill methods based PAIKEM (Pembelajaran Aktif, Inovatif, Kreatif, Efektif, dan Menyenangkan or Learning on Active, Innovative, Creative, Effective, and Joyful Learners) in order to improve fast reading skills of the learners at the Indonesia Youth Forum at West Sumatra (FIM Sumbar). Drill methods are used by repetitive exercise, but the material, techniques, and learning media used vary, so that student do not get bored, such as speed reading video media, maps, indigenous clothing of Indonesia, quick answer techniques, pair exercises, and preparation of the puzzle. The research used is the reseach action especially Elliot model. The subjects were chosen by purposive sampling. FIM Sumbar, which is posited as a collaborator, is an independent forum consisting of youth and students from various activities, universities and youth institution in West Sumatra with purpose to encourage the rising generation. Researcher serves as a teacher in the class. Learning media used in the form of video speed reading and puzzles according to the theme of the Indonesian folklore. Children as the subject of this study generally came from underprivileged group with cognitive basic skills are also low, but possess a high-learning spirit. After going through two cycles of activity, speed-reading skills of the learners increased significantly.
\end{abstract}

Keywords---speed-reading skills; drill method; PAIKEM; FIM Sumatera Barat

\section{INTRODUCTION}

Reading activity has a substantial social role in human life because it is useful for obtaining messages or information through the medium of words or written language which can not be separated from human need (Sutarji, 2016). Therefore, this skill also determines the quality of human resources (SDM) in a country. However, Ulwiah (2014) exposes a fact that-cited from Indonesian Publishing Association (IKAPI) in 2013-in Indonesia, a book is read by only 3-4 readers per year. Reflecting on the standards set by UNESCO, someone should be able to read up to 7 books in a year. This figure shows low interest in reading in Indonesia which then contribute to the quality of human resources in Indonesia in general.

The low level of reading interest is consistent with people's understanding about reading techniques that are equally low. Since in the mind of most people, reading activity is considered a common process that does not need to be seriously learned and developed. As a result, the reading skill of the general public, both speed reading and reading comprehension, tends to be stagnant. There is no expected improvement in step with the increased level of education, insight and knowledge of this community. In fact, Mulyati (2013), states that the assumption of speed reading will reduce the reading comprehension as a mistake. The activity of reading comprehension is essentially similar with the activity of understanding a speech. So, when someone is slow in listening to an utterance, then his/her understanding will also slow down. Similarly, if the speed of his/her reading is relatively slow, it will also lower his/her understanding.

1. Aware of different variations of reading goals;

2. Make a clear formulation on every reading activity, e.g., know what is obtained from the reading;

3. Need to develop a variety of reading strategies that are consistent with the range of reading objectives;

4. Need to practice reading with a variety of purposes;

5. Realize that someone who has high-determination on reading will be able to utilize every variation of reading technique according to the purpose of his/her reading.

One of the main issues from reading activities experienced by children these days is speed reading. This problem emerged because children reading skill is in the early stage of reading development which is marked by the spelling word for word. However, Mulyati (2013) argues that the introduction of speed reading will encourage students to more easily understand information in a text. This is in line with the typical nature of children who are filled with high curiosity about everything. Here is an explanation from Ulwiah (2014) towards speed reading techniques as follows:

(1) to minimize subvocalization whereby minimizing the sound or doing self talk; (2) skimming, specifically observing the text by looking for something important; (3) metaguiding through the use of finger or certain tool to point out the word being 
read and; (4) Rapid Serial Visual Presentation (RSVP) as a digital system to practice speed reading through displaying in sequential order one or more words at a time.

Warseno and Kumorojati (2011: 52) state that the basics of reading that need to be understood in order to have good fast reading ability are (1) relaxed, (2) in ready condition, (3) determining the purpose of reading, (4) understand the reading material, (5) getting the main idea of reading, (6) eliminating bad habits of reading, and (7) training the speed of eye motion and its ability of catching a word or more.

In addition to understanding these basic things, there are some stuff to know about matters that can obstruct speed of someone's reading. Soedarso (2004: 5) describes that in the following points: 1) vocalization, (2) lip movement, (3) head movement, (4) pointing with fingers, (5) regression, and (6) subvocalis.

Speed reading skill in this research is conducted through drill method. Drill is one of the methods in instruction that can also be interpreted as an exercise method. Hamdani (2009: 273) describes drill as a method that instructs students to employ repetitive exercises until the students have better skills on things they have learned. The key element lies in the process of repetition. This repetition attempts to form certain good habits (Asmani, 2009: 37-38). Furthermore, Majid reveals that the drill method works to develop skill and powess and develop valuable attitudes and habits (Majid, 2013: 214).

In keeping with the previous statement, Hamiyah (2014: 54) states that the drill method is a method of teaching by giving repetitive skills training to the learners and directing them to the training site to observe the process, purpose, function, usefulness and benefits of that matter. In this method, learning materials related to adeptness, skill, and prowess are well-suited.

In more detail, Irwahyudi (2009: 33) suggests that the purpose of using the Drill method in an attempt to encourage (1) motor/motion skills, such as memorizing words, writing, using tools; (2) intellectual skills, such as multiplying, dividing, and summing up; and (3) deductive reasoning

The negative consequence of the drill method in relation to repetition activities is to cause boredom. Therefore, it takes creativity to build a learning situation that is pleasing, but meaningful and beneficial. In this research, the Drill method is based on PAIKEM approach. Asmani (2011: 59) explains that PAIKEM is an approach that allows learners to work on diverse activities to develop skills, attitudes, and understanding with the emphasis of learning by doing. It means, the development of reading skills can also be applied with this approach.

The principle of PAIKEM refers to instruction on the basis of competence with the following principles: The principle of PAIKEM refers to learning on the basis of competence with the following principles (1) centered on learners; (2) integrals; (3) recognizing the individual uniqueness (4) gradual and thorough (mastery learning); (5) focus on problem-solving, and (6) multistrategy and multimedia (Budiana, 2014).

Furthermore, Hamzah and Nurdin (2012: 10) explain that PAIKEM includes (1) organizing learning materials, (2) delivering or use of learning methods, (3) instructional management oriented in the learning process. The Drill method based on PAIKEM in this research is applied in reading skill.

Speed reading skill with Drill method is managed in FIM Sumbar. FIM Sumbar is a community of Indonesian young generation in West Sumatra that is concerned in social issues especially providing education and guidance for underprivileged children in the city of Padang, West Sumatra.

\section{METHOD}

This research was based on Class Action Research (PTK) or mostly known as Action Research. This PTK was performed on student from FIM Sumbar in the age range of 6-12. The sample of this study amounted to 13 sudents. The purpose of this study was to improve students' speed of reading. The research design used Lewin's action research model interpreted by Elliot. The flowchart of PTK according to Elliot quoted from Depdiknas (2005) can be seen in the Figure 1. below.

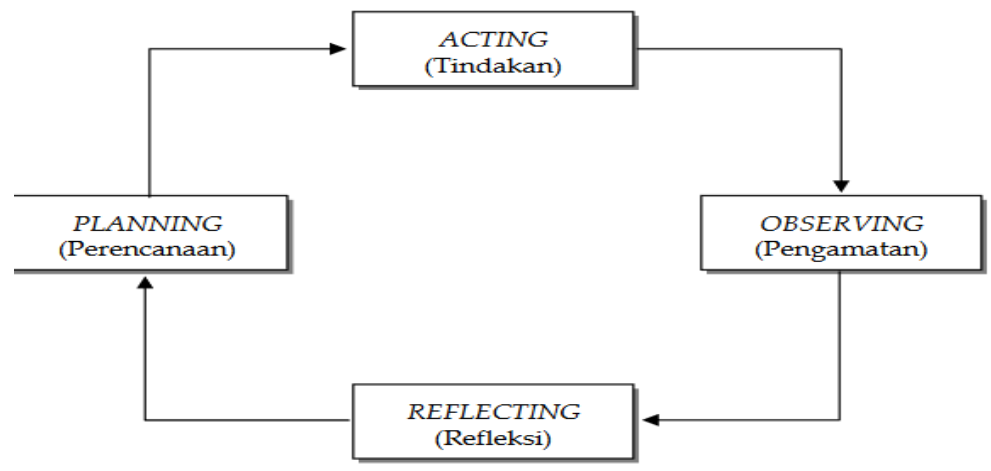

Fig. 1 The flowchart of PTK according to Elliot 
Data in this research consistted of two types, namely qualitative and quantitative data. Quantitative data referred to the speed of reading on the pupils of FIM Sumbar. The instruments of this research were about fast reading test in the form of text (reading material), reading comprehension sheet, field-note sheet either by researcher or collaborator (teacher of class), portfolio, and photos of activity. Meanwhile, the qualitative data covered all aspects related to the process of applying Drill method with PAIKEM approach. The display below was the formula for calculating the reading speed and the speed of effective reading.

\section{$\mathbf{k} \times \mathbf{6 O}$}

$\mathrm{Kmp}=$ reading speed (words per minute)

$\mathrm{k} \quad=$ total number of words read

$\mathrm{Wm}=$ the total number of words read per minute

$\mathrm{Wd}=$ the total number of words read per second

Halimahtussakdiah and Laurensia (2012) categorize the reading speed of elementary school children in Table 1. below:

Table 1. Reading Speed Category

\begin{tabular}{|l|l|}
\hline \multicolumn{1}{|c|}{ Reading speed } & \multicolumn{1}{c|}{ Reader profile } \\
\hline$>201$ & Sangat cepat/Hasty \\
\hline $151-200$ & Cepat/Quick \\
\hline $101-150$ & Sedang/Average \\
\hline $50-100$ & Lambat/Slow \\
\hline$>50$ & Sangatlambat/Sluggish \\
\hline
\end{tabular}

Sugiyono (2007) explains that validity and reliability test of data in qualitative research includes credibility test, transferability test, depenability test, and confirmability test with data triangulation technique involving researchers, collaborators (classroom teachers) and students and instruments test conducted by experts.

\section{A. Findings}

\section{FINDING AND DISCUSSION}

The students of FIM SumBar which are the subject of this research were elementary school students (SD). Therefore, the indicator of the achievement of this research is based on reading speed indicator on elementary-school level. After doing some field observations, the level of students' reading speed from FIM SumBar is low. To prove this case, the researchers conducted a pre-test. Pre-test is a test given to a research subject prior to classroom action. The purpose of pre-test was to determine the basic ability of research subjects. After the first-cycle of class action, a first-cycle test was also conducted that aims to see the development of students' reading skills in that cycle. If there is no significant increase, then it is forwarded to the next cycle.

Based on the discussion with the collaborators, the success indicator of this research was the average reading speed of students. The students' reading speed was in the slow category that had a reading speed in the range of 50-100 words per minute (wpm). Since the first cycle results had not met the success indicator then it continued to the second cycle of the class action. Next, in order to examine the success of this second-cycle, a second-cycle test was performed. The second-cycle test indicated a considerable increase in the students' reading speed. The average reading speed of the students in this second-cycle test was in the average category, which is 101-150 wpm. The average reading speed of students in this second cycle test is in the moderate category, which is 101-150 kpm range. The reading-speed data of students from FIM Sumbar can be seen in the Table 2 below.

Table 2. The reading-speed data of students from FIM Sumbar

\begin{tabular}{|c|c|c|c|c|c|c|c|c|c|c|}
\hline \multirow[b]{2}{*}{ No. } & \multirow{2}{*}{$\begin{array}{l}\text { Test } \\
\text { phase }\end{array}$} & \multicolumn{3}{|c|}{ Pre-test } & \multicolumn{3}{|c|}{ First-cycle test } & \multicolumn{3}{|c|}{ Second-cycle test } \\
\hline & & $\begin{array}{l}\text { Percen } \\
\text { tage }\end{array}$ & $\begin{array}{l}\text { Quality } \\
\text { score }\end{array}$ & \multirow{7}{*}{$\begin{array}{l}\text { Classical } \\
\text { average } \\
\frac{627}{13} \\
=\quad 48,23 \\
\text { sluggish }\end{array}$} & $\begin{array}{l}\text { Percent } \\
\text { age }\end{array}$ & $\begin{array}{l}\text { Quality } \\
\text { score }\end{array}$ & \multirow{7}{*}{$\begin{array}{l}\begin{array}{l}\text { Classical } \\
\text { average }\end{array} \\
\frac{1272}{13} \\
=\quad 89,8 \\
\text { slow }\end{array}$} & $\begin{array}{l}\text { Percentag } \\
\mathrm{e}\end{array}$ & $\begin{array}{l}\text { Quality } \\
\text { score }\end{array}$ & \multirow{7}{*}{$\begin{array}{l}\begin{array}{l}\text { Classical } \\
\text { average }\end{array} \\
\frac{2064}{13} \\
=158.78 \\
\text { average }\end{array}$} \\
\hline 1 & $>201$ & 0 & 0 & & 0 & 0 & & $23 \%$ & 707 & \\
\hline 2 & $151-200$ & 0 & 0 & & 7,7 & 186 & & $7.7 \%$ & 525 & \\
\hline 3 & $101-150$ & 0 & 0 & & 46.14 & 616 & & $38.46 \%$ & 673 & \\
\hline 4 & $50-100$ & 38.46 & 339 & & 30.76 & 280 & & $30.76 \%$ & 159 & \\
\hline 5 & $>50$ & 61.54 & 288 & & 15.4 & 86 & & 0 & 0 & \\
\hline Tota & & $100 \%$ & 627 & & $100 \%$ & 1272 & & $100 \%$ & 2064 & \\
\hline
\end{tabular}


Based on the above table, it can be seen that after doing the pre-test, reading speed and KEM of the subject is in the sluggish category (around 61.54\%) and low-category (38.46\%). The classical rate of pre-test results indicated that th reading speed of the subject was in the sluggish category (about 48.23 wpm).

The test results in the first cycle showed a major development. The subject in sluggish category reduced to $15.4 \%$; the slow category decreased to $30.76 \%$; the medium category increased to $46.14 \%$. Moreover, there was a student who had reached the quick category. In term of classical, the test results from this first cycle pointed out that the reading speed of the students was in slow category.

The results of the second test demonstrated a considerable rise. Approximately $23 \%$ of children reached rapid category, while around $7.7 \%$ managed quick category, and about $38.46 \%$ of students attained average category. Meanwhile, the students in sluggish category were no longer found. However, about $30.76 \%$ of the total students are in the slow category. The classical rate of the second cycle indicated that the reading speed of subject has been changed to the average category. The bar chart of each student's reading speed can be seen in the Figure 2. below.

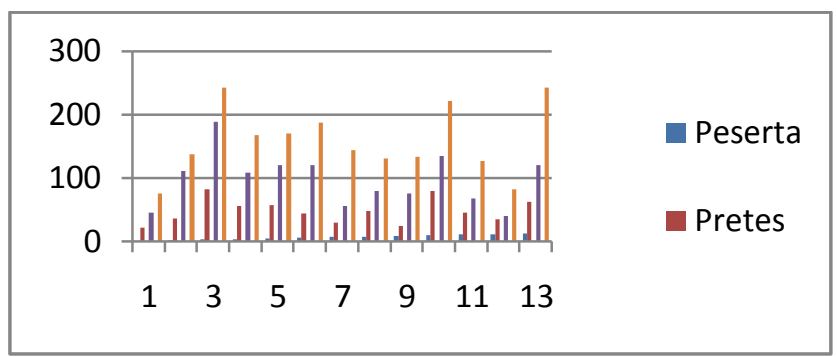

Fig. 2. The graphic of students' reading speed from FIM Sumbar

\section{B. Discussion}

This research used two cycles. Every cycle used action research of Elliot model; it included preparation, implementation, observation, and reflection. We used drill method in every cycle; however there is variation in media and insturctional technique.

First cycle activity

Preparation stage

After knowing the appaling result of pretest toward the children, researcher and class teacher (collaborator) discusssed methods, approaches, and learning media in order to improve reading skills of the children. The children are elementary school level who usually easily getting bored, so the selected learning method should be attractive and inspirative. Besides, researcher also provided regular exercise that is systematic and continual or drill.

The planning of first cycle included (1) making RPP (Lesson Plan); (2) choosing of text which is suitable for the children; (3) deciding total number of practices; (4) choosing interesting quiz (trivia guess); (5) the creating of instructional media, such as the picture that is match with the text, and (6) making star-badge as achievement sign as well as time marker.

\section{Implementation stage}

Every implementation stage of action research consists of apperception activities (introduction), core activities, and closing. This activity is listed in learning plan. In addition, it also contains certain method, technique, and assessmen.

First cycle has been done about two times practice that using two texts. Before starting the instruction, the teacher arranged children's seats. This cycle is carried out at classroom (usually outdoors) caused by heavy rain. Apperception activity provided an explanation towards the nature of the reading activity and its purpose briefly. In this first meeting, the students are very passive and tend to be more quiet evenmore when they are asked which is understand or not they answer it silently. Because of that, the teachers should more active and tried to give an opportunity for every child to answer in order. However, this activity is ineffective bacuse children were not interested.

In the core activity, the teachers wrote some obstacles in speed reading activity. The teachers asked and guided the childen to fill the obstacle table. Based on the answers of the children, the general result is accordance with the habits as stated by Soedarsono (2003) i.e., 1) vocalization; (2) lips movement; (3) head movement; (4) pointing with finger; (5) regression; dan (6) sub-vocalist. Based on that matter, teachers guided the children to practice and to decrease every number of their obstacle. Teachers exemplified the activities in every number. Teachers carried on these activities continuously with regard to the example because children are still confused and difficult, even some of them looked exhausted. However, the teachers did intensive approach and convince the children about the easier procedure, but it needed time and regular practices. After the kids began to understand the material, the teachers conducted speed reading test.

In the first exercise, the children provided the text with title "Kesatria Burung Garuda". The teachers gave one minute (using stopwatch) to children for reading. After one minute, the children were asked to give mark on their last reading. Next, the children were given another one minute to continue their reading. It was repeated until they finished their readings. Next, the teachers guided the children to calculate the words that are read in minute per minute. The accumulation was given to the teachers, and it was discussed by collaborator and the other researcher members. 
After finishing the reading stage, the next activity was a quiz; it aimed to examine the reading comprehension of the children. In this quiz, researchers provided some pictures related to the reading. The task of the children was to embed the images according to teachers' question. For example, "Where did the folklore come from?" Then, the kids should compete to embed the pictures that are match with the question. It was done until 5 questions. In every correct answer, the kids got a star. This star was used to decide who is the best participant. In this phase, the children started to be enthuastic to the game.

For second exercise, these kids were given a folklore text with title "Legenda Danau Maninjau", folklore from West Sumatera. The exercise in the first step was repeated on this second exercise. In this exercise, teachers did not use pictures anymore but essay task.

In the last step or closing, teachers summarized the entire instructional points which are (1) message or moral values from folklore; (2) values and the reading speed of children; and (3) giving homework (PR) to the children to enlarge fast reading exercise at house because on the next meeting, there would be fast reading competition.

Based on the observation and reflection of the first cycle, the implementation of second cycle had been done using more representative media. The teachers used infocus to display the theory and videos about fast reading. The children were more enthusiastic and excited in the instruction. They were amazed with the other kids in that video and motivated to read much faster. In order to recognize the understanding of children, the teachers examined every child to demonstrate each thing that slowed up fast reading activity. On this cycle, these children looked much braver to stand in front of the people and to answer question. Evenmore, the children asked a lot of things about tips for fast reading.

There were two folklore texts that are given in the second cycle, "Legenda Danau Toba" and "Legenda Danau Batur". Different with previous cycle, in this second cycle the children began to concentrate better as seen from their sitting position and attitude to the texts. The practice was given similar with previous meeting; teachers gave one minute (using stopwatch) to the kids to read the text for regular three stages. After that, teachers gave a chance to children to finish their reading based on their speed. For fastest students, they should report it with raising hand and got stars as achievement of their effort. For a child who finished first, he/she will be getting 5 stars; the second will be getting 4 stars; the third will be getting 3 stars; the fourth will be getting 2 stars; and the slowest will be getting one star. Time recording was done by collaborator and the other research teams.

After reading activity was finished, the next activity is reading comprehension exercise. The difference is the questions are multiple choices in this second cycle. The rules for this activity, every student who give wrong answer will get powder on his face whereas the right ones will get one star and allow to cross out his/her friends' face that give wrong answer. This activity is exciting and interesting; it also teaches the children about a risk over every mistake. The students enjoyed this activity. The result of this activity indicates that reading comprehension of the children is better than the exercises on the first cycle.

Before starting the next exercise, the teachers gave intermezzo to the children in the form of watching video. Besides giving a break for awhile to make them relax, this activity was used to strengthen their comprehension about the stories of the archipelago.

This second exercise in this second cycle is not really different with previous one. Teachers used comprehension text question with puzzle method; the question given is behind a map, the location of the origin of folklore that was read before. Therefore, the children needed to arrange that puzzle correctly in order to read and finish those questions. The questions were made in 10 multiple choices.

The last step or closing stage in this second cycle was similar with first cycle. However, teacher inserted some messages and impressions after the children finished the learning. On this second cycle, the children mostly expressed their happiness and want to read much faster. The children realized that fast reading is necessary because they should share their time for other activities such as helping the parents in trading, schaveging, or helping some other homework.

\section{Observation Stage}

Every learning activity was observed, recorded, and documented by researchers and the other team members also collaborator that was written in field notes. Besides, the observation was completed by documentation, either photos or videos.

The result of observation in the first cycle is passive. The children do not enjoy and understand the learning; it is marked by low rate of participation of the kids. The teachers are "overwhelmed" and "awry" because student's passivity and slowness of the children in understanding the instruction.

\section{Reflection Stage}

The reflection stage is useful to see the learning as a whole aspects i.e., activities between students and the teachers, time and method effectivities, and representation of media that is used. There are some notes in the first cycle: (1) the activity level of the children is passive; (2) the time is not yet effective, (3) instructional media is not really optimal, (4) seat and the position of the children need to be arranged, (5) the teachers have not mastered the class, and (6) quiz or exercise test should be in multiple choice to make the students more understand.

On the other side, the second cycle-after revision based on reflection of first cycle-manages more interesting instruction for the children. Revision notes from first cycle are conducted optimally so as the instruction become greater. It can be seen from the progress of the reading speed, improvement on participation, and reading comprehension of the children. 


\section{Second Cycle Activity}

\section{Planning Stage}

The planning activities for second cycle include (1) revising lesson plan and instructional media (using video) and technique; (2) selecting of the reading text that is suitable for children in second cycle and marking group of word in the text until they are used to read based on group of word, not word per word; (4) deciding and making various exercise also interesting quiz (multiple choice questions and puzzle).

\section{Implementation Stage}

The implementation of second cycle applied more representative media. The teachers utilized infocus to display theory and video about fast reading. The children looked like more enthusiastic during instruction. They were amazed with the other kids in that video and motivated to read much faster. In order to recognize the understanding of children, the teachers examined every child to demonstrate each thing that slowed up fast reading activity. On this cycle, these children looked much braver to stand in front of the people and to answer question. Evenmore, the children asked a lot of things about tips for fast reading.

There were two folklores in this second cycle namely "The Legend of Toba Lake" and "The Legend of Batur Lake." It is different rather than previous cycle, the children started to concentrate better as seen from their seat position and the attitude towards the text. The exercise is given identical with the previous meeting. The teachers gave one minute (using stopwatch) to the children and asked them to read it three times. Next, the teachers gave opportunity to the children to finish the reading based on their speed. For fastest students, they should report it with raising hand and got stars as achievement of their effort. For a child who finished first, he/she will be getting 5 stars; the second will be getting 4 stars; the third will be getting 3 stars; the fourth will be getting 2 stars; and the slowest will be getting one star. Time recording was done by collaborator and the other research teams.

After reading activity was finished, the next activity is reading comprehension exercise. The difference is the questions are multiple choices in this second cycle. The rules for this activity, every student who give wrong answer will get powder on his face whereas the right ones will get one star and allow to cross out his/her friends' face that give wrong answer. This activity is exciting and interesting; it also teaches the children about a risk over every mistake. The students enjoyed this activity. The result of this activity indicates that reading comprehension of the children is better than the exercises on the first cycle.

Before starting the next exercise, the teachers gave intermezzo to the children in the form of watching video. Besides giving a break for awhile to make them relax, this activity was used to strengthen their comprehension about the stories of the archipelago.

This second exercise in this second cycle is not really diverse with previous one. Teachers used comprehension text question with puzzle method; the question given is behind a map, the location of the origin of folklore that was read before. Therefore, the children needed to arrange that puzzle correctly in order to read and finish those questions. The questions were made in 10 multiple choices.

The last step or closing stage in this second cycle was similar with first cycle. However, teacher inserted some messages and impressions after the children finished the learning. On this second cycle, the children mostly expressed their happiness and want to read much faster. The children realized that fast reading is necessary because they should share their time for other activities such as helping the parents in trading, schaveging, or helping some other homework

\section{Observation Stage}

Different with the first cycle, the instruction in the second cycle runs livelier. The children even try to strive each other in order to answer the quiz; they are also more excited in every learning activity. The teachers look more enjoys and capable to handle the class so as the instruction manages smoother and meaningful.

\section{Reflection Stage}

Meanwhile, the second cycle-after revision based on reflection of first cycle-manages more fascinating instruction for the students. Revision notes from first cycle are conducted optimally so as the instruction become greater. It can be seen from the progress of the reading speed, improvement on participation, and reading comprehension of the children.

\section{CONCLUSION}

The Drill method based on PAIKEM in speed reading instruction utilizes fast reading exercises regularly interspersed with fun and meaningful game exercises, such as guessing random pictures, face doodling, and puzzle quiz. After doing the examination in two cycles, the reading speed of the students (children) of FIM Sumbar is growing significantly. The former reading speed of students before the implementation of Drill method is in sluggish/very-slow category. After applying the Drill method, the reading speed increases from slow until average category. Nevertheless, the exercise of speed reading should be managed continuously and regularly in order to improve the average reading speed of the students of FIM Sumbar until reaching quick or hasty category.

\section{References}

Asmani, Jamal Ma’mur. (2011). 7 Tips aplikasi PAKEM. Jogjakarta: DIVA Press.

Budiana, Diki. 2014. "Prinsip-Prinsip PAIKEM". http://kikibudiana.blogspot.co.id/2014/06/prinsip-prinsip-paikem.html. Diakses 7 September 2017. 
Depdiknas. (2005). "Penulisan karya ilmiah" dalam materi pelatihan terintegrasi jilid 3. Jakarta: Depdiknas Dirjen Pendidikan Dasar dan Mengengah Direktorat Pendidikan Lanjutan Pertama.

Halimatussakdiah dan Laurensia. (2012). "Meningkatkan kemampuan membaca cepat siswa sekolah dasar". Dipublikasikan dalam Kegiatan Seminar Hasil Research Grant di Lemlit UNIMED pada tanggal 6-8 Nopember 2012. Diunduh dari http://download.portalgaruda.org/article.php?

article $=176843 \& \mathrm{val}=5579 \&$ title=MENINGKATKAN\%20KEMAMPUAN\%20MEMBACA\%20CEPAT\%20SISWA \%20S EKOLAH\%20DASAR. Diakses 23 Mei 2017.

Hamdani, M.A. (2009). Strategi belajar mengajar. Bandung: CV. Pustaka Setia.

Hamiyah, Nur. (2014). Strategi belajar mengajar di kelas. Jakarta: Prestasi Pustaka.

Irwahyudi, Wildan. (2009). "Penerapan metode resitasi dan metode drill sebagai upaya meningkatkan hasil belajar siswa kelas III pada pelajaran matematika di SDN Pulerejo 02 Bakung Blitar.” Skripsi. Dalam www.uin-malang.ac.id.

Majid, Abdul. (2013). Strategi pembelajaran. Bandung: Remaja Rosdakarya.

Mulyati. (2003). “Kecepatan membaca efektif: apa dan bagaimana?". Disajikan dalam Diklat Membaca, Menulis, dan Apresiasi Sastra bagi Guru-Guru SLTP Se-Indonesia, Tanggal 1s.d. 14 Oktober 2003 di PPPG Bahasa Jakarta. Jakarta: Departemen Pendidikan Nasional Dirjen Pendidikan Dasar dan Menengah Pusat Pengembangan Penataran Guru Bahasa.

Nurhadi. (2010). Bagaimana meningkatkan kemampuan membaca. Malang: Sinar Baru Algensindo.

Soedarso. (2004). Sistem membaca cepat dan efektif. Jakarta: Gramedia.

Sugiyono. (2007). Metode penelitian pendidikan (pendekatan kuantitatif, kualitatif, dan R\&D). Bandung: Alfabeta.

Sutarji, Dedi. (2016). "Keterampilan membaca dan menulis". Diunduh dari http://www.kompasiana. com/dedisutarii/keterampilan-membaca- dan-menulis 58367011907e61a714313ebb. Diakses 17 Agustus 2017.

Ulwiah, Ria. 2014. "Teknik-teknik membaca cepat". Artikel. Diunduh dari http://Aquariusnote.com/teknik-membaca-cepat. Diakses 27 Juni 2017.

Uno, Hamzah . (2012). Belajar dengan pendekatan PAIKEM. Jakarta: Bumi Aksara.

Warseno, Agus dan Ratih, Kumorojati. (2011). Super Learning. Yogjakarta: Diva Press. 